\title{
牛の乳房炎に関する研究
}

\section{II. 乳房炎牛に和ける乳房内細菌叢について}

\author{
越智 舫一・勝 部 泰次 \\ (東京大学農学部獣医学科家畜細菌学教室)
}

(昭和 33 年 4 月 25 日受付)

私共は前報0に心いて．牛の乳房炎の原因学的研 究の基濋として, 健康牛の乳房内正常細囷叢につい て検菜し、健䈴牛の乳房は無菌的な器官でなく, 各 耗の細藏が存在するとと報告した.

本症の原因については，古くから多くの研究が行 われ，各種の細菌，乳房执よび乳頭の損傷，不適当

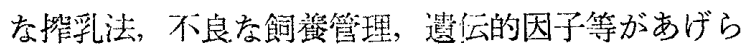

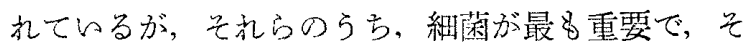

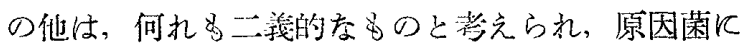
関する研究が最早重琵視された。即ち, NOCARD and Mollereau (1887), BANG (1889) 等によつ て, 初めて Streptococcus の重琵性が報告されて以 来 ZSCHOKKE (1897), CARPENTER (1924, 1925). Mejlbo (1924), Lourens (1927), HARdenBERGH et al. (1927)3), RUDOLF (1927-8), MINETT et al. (1929), SCHuMANN (1929), Connecticut Agr. Exp. Sta. (1931), ClaAsSEN (1931), LOURENS ( 1934), STYLIANOPOULOS (1934), SChlotthauer $(1944)^{9)}$, Hughes $(1954)^{5)}$

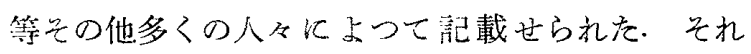
らの報告を通覽すると，およ先 60〜90\% は St reptococcus に上与が, 本菌以外保 Staphylococcus, Coliform, Corynebacterium pyogenes が, また 少数例加り Pseudomonas acruginosa, Bacteroideac, Pasteurella, Clostridium welchii 等が検 出されている. その他 Klebsiella pneumoniae, ${ }^{1)}$ Cryptococcus, ${ }^{11)}$ Actinomyccs 等飞よる乳房炎の発 生も報告せられている.

彷来，本症は Streptococcus による慢性乳房炎が 最も多く, なかでも Streptococcus agalactiae が 主要を原因であり，本菌は乳房にのみ寄生性を有す る特殊な病原菌と夕なされ，從つて，本症の鶜断，予 防标よび治療対策等多, 主としててれを対象として

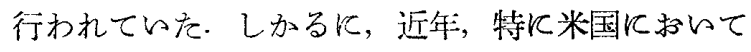
は，本菌に上る孚房炎は減少したといわれ，その原 因の一部上して、抗生物筫による治療があげられて
いる. 即ち, BURKEY et al. (1946) ${ }^{2)}$ とる，1945〜 1946 年にわたる調査を見ると，Streptococcus の検 出率は依然として主位を占めているが，そのらち， Str. uberis が最多多く,ついで Str. viridans, Str. dysgalactiac, Str. fecalis 等の順に検出され, Str. agalactiae の検出率は最多低率であり，また SCHALM et al. $(1953)^{8)}$ \&同様K Str. agalactiae による乳房炎は減少し, Staphylococcus, Coliform, Pseudomonas 等による乳房炎が増加の傾向にある ¿い5.

以上の成績は, 何れ妟欧米に抽て認められたも のであるが，我国に沶いては，本症に関する研究は 少く，僅に，二三を数えるに過ざないが，清水 $(1951)^{10)}$ の北海道に利ける調查では, Streptococcus の検出率高く,ついでグラム陰性桿菌, Staphylococcus, Cory. pyogenes と索り, 欧米に和ける成績に比 し, Str. agalactiae の検出率低く, グラム陰性桿 菌が高率であつたといい，また平户等 $(1956)^{4)}$ の北 海道に䏡ける四地区の調査では, Staphylococcusの 検出率最宲く, ついで Streptoccus, Micrococcus 等を認好，占田等 $(1955)^{12)}$ は，米国におけると同 様に乳房炎原因菌は变化していると報告している.

上述の如く，本症原因としては，各種の細菌が あげられているが，とれらの菌種と同種同属の多の は, 通常健康乳房から検什世られている. しかる 飞, 現在本症の診断は, 臨床症状を有するものは別 として, 主として乳汁より検出された菌種と, 乳汁 中の細胞数あるいは乳汁の生化学的性状等の関連に おいて行われているが，前述の如く，乳房は無菌的 な器官でなく, 各種の細菌が存在し, また, 細胞数 あるいは生化学的性状等は, 単に菌の感染増殖のみ によつて変化するものでなく，それらの生理的動摇 籁囲はかなり広いものであるため，本症の診断に当 り，非常な混乱を生じている，従つて，本症の原因 は甚だ不明瞭で, 殆ど未解决の状態であるといつて も過言でないよらに思われる。 
Table 1. Frequency and Quantity of Organisms Isolated from Cases of Mastitis

\begin{tabular}{|c|c|c|c|c|c|}
\hline Organisms & $\begin{array}{c}\text { Colonies } \\
\text { on } \\
\text { Agar } \\
\text { Flate } \\
\text { Cases }\end{array}$ & $\begin{array}{c}+ \\
1 \sim 9\end{array}$ & $\begin{array}{l}+4 \\
10 \\
\widetilde{99}\end{array}$ & $\begin{array}{c}+1 \\
100 \\
\sim \\
299\end{array}$ & $\begin{array}{c}\text { 册 } \\
\text { over } \\
300 \\
\end{array}$ \\
\hline $\begin{array}{l}\text { Lactobacillaceae } \\
\text { (Streptococcus) }\end{array}$ & 75 & 12 & 28 & 20 & 15 \\
\hline Bacillaceae & 51 & 19 & 29 & 3 & \\
\hline Micrococcaceae & 43 & 16 & 19 & 6 & 2 \\
\hline $\begin{array}{c}\text { Gram-negative } \\
\text { bacilli }\end{array}$ & 39 & 11 & 17 & 7 & 4 \\
\hline Corynebacteriaceae & 20 & 5 & 4 & 2 & 9 \\
\hline
\end{tabular}

そとで私共は, 正常細菌箸しの比較において, 本 症の原因学確めるためにいるいろの研究を行つてい るのであるが，そのうち本報においては，病理解缡 学的に明瞭飞認譏し得る乳啳炎の細菌学的検索につ いて能載する。

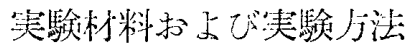

本研究は，第 1 回 1955 年7月より11月，第 2 回 1957 年 5 月より11月までの間に, 東京都芝浦と畜 場に私いてと殺せられた乳牛のらち, 解体剖検時, 乳 房に闪眼的に明瞭な病巣が認められ, 碓奏に乳房炎 上骖哳された総計 100 頭について行つたものであ る.これら罹患牛の飼育地, 本症発症後の経過, 治 瘵の椎無等については不明である。尚, 病洋部の肉 眼的所見はすべて化膿性の病変であつたが，そのら ちて例は膿湯を形成していた。

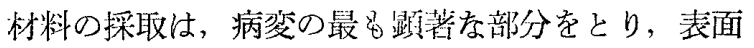
を十分にスパーテルで焼俻した後, 深部組織（表面

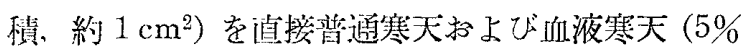
に馬あるいは緬羊脱線血を加える)壮板士に叙抹し， $37^{\circ} \mathrm{C}$ K 18 洔間培養した。

\section{类跧 成 緒}

総計 100 例について検案したが， その成續を総括 すると，97例より各種の菌が新明され，3例からは 䒩が検出されなかつた。

病紧部より検出された菌種を検出頻度並びに菌数 別に整理して見ると Table 1 亿示寸如く, Lactobacillacece (Streptococcus) の梌出率最名高く,つ 々で Bacillaceae, Micrococcuçaっ, グラム陰性桿菌, Corynebacteriaceae となり、汗板.上集落数が 100 個以上に検出された場合は，Lactobacillaceae (Streptococcus) Kよる?のだ米数を占め, ついで
Table 2. Bacterial Flora Appeared in Cases of Mastitis

\begin{tabular}{|c|c|}
\hline Organisms & $\begin{array}{c}\text { Number } \\
\text { of } \\
\text { Cases }\end{array}$ \\
\hline Lact. & $30(23)^{*}$ \\
\hline Micro. & 5 \\
\hline G. $-\mathrm{R}$. & $4(3)$ \\
\hline Coryne. & $3(2)$ \\
\hline Lact. $\quad+$ G. - R. & $13(8)$ \\
\hline Lact. + Micro. & $12(7)$ \\
\hline Micro. + Coryne. & $4(2)$ \\
\hline Coryne. + G.-R. & $2(1)$ \\
\hline Lact. $\quad+$ Coryne. & $1(1)$ \\
\hline Micro. + G.- R. & 1 \\
\hline Lact. + Micro. + G.-R. & $12(2)$ \\
\hline Lact. + Micro. + Coryne. & $3(2)$ \\
\hline Micro. + Coryne. + G. - R. & 3 \\
\hline Lact. + Coryne. + G.-R. & 1 \\
\hline Lact. + Micro. + Coryne. + G. - R. & 3 \\
\hline Negative & 3 \\
\hline 1 otal & 100 \\
\hline
\end{tabular}

( ) Figures given in parenthesis indicate number of cases which isolated with small number of Bacillaceae.

Lact.: Lactobacillaceae (Streptococcus).

Micro.: Micrococcaceae.

Coryne.: Corynebacteriaceae.

G-R.: Gram-negative bacilli.

Corynebacteriaceae，グラム陰性桿菌, Micrococcaceae であつた.

Bacillaceae の検出频度は，Lactobacillaceae (Streptococcus) についで多かつたが，菌数汁少く， 本菌の検出され荡合, その平板上集落数は 50 個 以下のものが大部分であつた。

これらの备菌種の検出状態は Table 2 亿示す如 く, Lactobacillaceae (Streptococcus) は 30 例, Micrococcaceae は 5 例, グラム陰性桿菌は 4 例, Coryncbacteriaceae は 3 例に打いて何机多純粋ま をは少数の Bacillaceae と混在して検出されたが， 他は 2 3 種の菌が同時に检出女られ，特に Lactobacillaceae (Streptococcus) とグラム陰性桿菌, Lactobacillaceae (Streptococcus) ¿ Micrococcaceae, Lactobacillaceae (Streptococcus) \& Micrococcaceae 拉よびグラム陰性桿菌の混在しを例が多 かつた.

また Bacillaceae を除を，他の2〜3 種の菌が混 在して检出された 55 例中，21 例は Lactobacilla- 
ceae (Streptococcus), 8 例は Corynebacteriaceae, 5 例计グラム陰性桿菌，4例は Micrococcaceae が， それぞれ，他の菌種に比へ懮勢に検出されたが，そ の他については，量的に特に優少は認められなかつ tr.

以上の成續は，一期に分けて行つた䒠駼結果をま とめたものであるが，両期の間に検出された菌種の

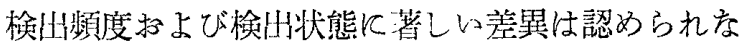
かつ老。

\section{若祭並じに総括}

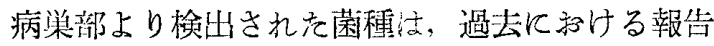
と略々同様に Lactobacillaceae (Strcptococcus) が 最多多く，その他の菌の检出率㤬低加た。

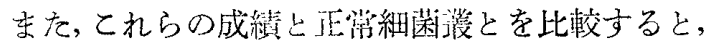
检出された菌種は略タ同棒であるが，菌種別の梌骀 频度奻異り，Lactobacillaceae (Streptococcus) は 裔率であり，Micrococcaceae 执よで Corynebacteriaceae の檢出率怟く、グラム除性桿菌はやや 亩率であつた。

先飞述べた如く，現在，乳房炎原因菌はStr agalactiae 以外の菌種に移り変つて行く傾向が報告

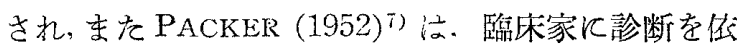
頪された乳汁について梌系し, Iowa 州においては, 本症の原因として Staphylococcus aureus が重要 であると強調しているが，私共の研究は 1955 年和 よび 1957 年に行われをるのでるが，両期に和け

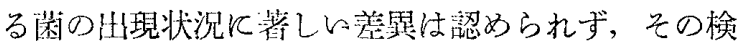
计頻度および検出状態より見て，Lactobacillaceae (Scrcptococcus) は侁然として贸安重要を菌種と考 えられる。

尚，病巣部より検出さ礼を各菌種が，本病巣形成 に当り,真に意義を有していたか否かについては, 正

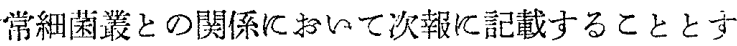
子.

以上の成績を総括すると次の如くである.

1)と殺㓯検時，乳房に肉眼的に明瞭な病棵が認め られ，確夆に乳房炎と骖阯された 100 頭について， 細菌学的検菜を行つをとこる，乞の97 例より备 種の菌が検出された。

2）検出されを菌種は 5 種にわたり，その检出㵋度 は次に示す通りである.

(1) Lactobacillacexe (Strcptoccus) $75 \%$

(2) Bacillaceae $51 \%$
(3) Micrococcaceae $43 \%$

（4）グラム陰性桿菌 39\%

(5) Coynebacteriaceae $\quad 20 \%$

3) とれらの菌種の検出状態は, Lactobacillaceae (Streptococcus) は 30 例, Micrococcaceae は 5 例, グラム陰性棉菌壮 4 例, Corynebacteriaceae は 3 例に，それぞれ，純粋または少数の Bacil laceae と混在して検出され，また，Bacillaceae 以外の菌種が $2 \sim 3$ 種が混在して検出された 55 例 中，21 例は Lactobacillaceae (Streptococcus)， 8 例は Coryncbacteriaceae, 5 例はグラム陰性 㙕菌が，4 例は Micrococcaceae，元れぞれ，他 の菌種に比べ優勢であつを。

1）以上の成續は，二期に分けて行つを多のを総括 したものであるが，雨期の間に，検出された囷種 の检出頻度扔をび梌出状態儿著し的差異は認るら れなかつ变。

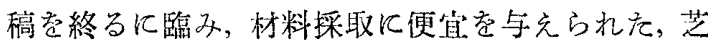
浦と畜場検查員各位に深く感謝の意堂します。

文献

1) Barnes, L. E.: J. Amer. Vet. Med. Ass, 125, 50 (1954).

2) Burkey, L. A., Swett, W. W. and C. R. BuCkner: J. Dair. Sci., 29. 528 (1946)

3) Hardenbergh, J. G. and C. F Schlot' HAUER: J. Inf. Dis., 40, 667 (1927).

4) 刊等：日獣会誌, 9, 159 (1956).

5) Hughes, D. L.: Vet. Rec., 66, 235 (1954).

6) 越智・勝部：日本㽞医学雑誌，20,39 (1958).

7) Packer, R. A.: North Amer. Vet., 33, 777 (1952).

8) Schalm, O. W. and G. M. WOOD: $J$. Amer. Vct. Med. Ass., 122, 462 (1953),

9) Schlotthauer, C. F.: North Amer. Vet., 25, 84 (1944).

10）清水：日獣全誌，4,108 (1951).

11) Simon, J., Nichols, R. E. and E. V. Morse: J. Amer. Vet. Med. Ass., 122, 31 (1953).

12）吉旧 - 桐沢 - 兼清：日獣会誌, 8, 164 (1955). 


\title{
STUDIES ON BOVINE MASTITIS
}

\section{BACTERIAL FLORA IN THE UDDERS OF MASTITIS COWS}

\author{
Yuichi OCHI and Yasuji KaTsuBE \\ Dcpartmont of Bacteriology, Division of Veterinary Science, Faculty of Agriculture, \\ University of Tokyo
}

(Received for Publication April 25, 1958)

As one of the basic studies of bovine mastitis, the authors reported previously on the normal bacterial flora in the udders of healthy cows. ${ }^{6}$ In this report, the bacterial flora of the cows suffering from mastitis were investigated for clarification of the causative agents of the disease.

Examinations were made on 100 udders of cows found to have suffered from mastitis on post-mortem examination. All the udders showed macroscopic, purulent lesions and in some cases (7) abscesses were formed. Cultures were made from these lesions on both nutrient agar and blood agar plates, for 48 hrs. at $37^{\circ} \mathrm{C}$ under aerobic condition.

1. Bacterial isolation from the lesions was positive in 97 out of the 100 udders examined.

2. Bacteria belonging to the following families were recovered from the lesions with rate of appearance in the order listed.

$\begin{array}{ll}\text { Lactobacillaceae (Streptococcus) } & 75 \% \\ \text { Bacillaceae } & 51 \% \\ \text { Micrococcaceae } & 43 \% \\ \text { Gram-negative bacilli } & 39 \% \\ \text { Corynebacteriaceae } & 20 \%\end{array}$

3. Lactobaccillaceae (Streptococcus), Micrococcaceae, Gram-negative bacilli and Corynebacteriaceae were isolated from 30,5,4 and 3 cows respectively, in the state of almost pure culture, or, in combination with a small number of Bacillaceae. Out of the 55 cows from which 2 or more kinds of micro-organisms were isolated aside from Bacillaceae, Lactobacillaceae (Streptococcus) was predominant in 21, Corynebacteriaceae in 8 , Gram-negative bacilli in 5 and Micrococcaceae in 4.

4. The above mentioned results were summarized from data obtained on two occasions the first from July to November 1955 and the second from May to November 1957. No considerable difference was observed in the organisms recovered between the time of those two investigations. 